\title{
MENYOAL KESENJANGAN ANTARA DAS SEIN DAN DAS SOLLEN PENYEBARAN ISLAM PRA WALISONGO
}

\author{
Widiastuti \\ Fakultas Psikologi dan Kesehatan UIN Walisongo Semarang \\ Email: widiastuti_sl319@walisongo.ac.id
}

\begin{abstract}
This Artikel based on historical research. The result of research was indicated thats Islam has been spread in Java since the 7th century, and has even successfully Islamized two Javanese priyayi namely Rakeyan Sancang from Tarumanegara and Prince Jay Shima from Kalingga. However, the reality of data on the development of the number of Javanese Muslim communities from the 7th-14th century AD was minimal. This fact tell about the passive indigenous Muslims. While in the Walisongo (14-16 AD), in a relatively short span of time was able to change the number of Muslim minorities into the majority. Thus, in the history of pre-walisongo Islam spread the imbalance between hope and reality arises. The spread of prewalisongo Islam has taken a very long time, so the expectation is to produce significant quantity and quality development of Muslim societies. But the fact that it did not materialize because the spread of Islam is less successful both in quantity and quality.

Artikel ini didasarkan pada penelitian sejarah. Hasil penelitian menyatakan bahwa Islam sudah disebarkan di Jawa sejak abad $7 \mathrm{M}$, bahkan telah berhasil mengislamkan dua priyayi Jawa yaitu Rakeyan Sancang dari Tarumanegara dan Pangeran Jay Shima dari Kalingga. Akan tetapi, kenyataannya data tentang perkembangan jumlah masyarakat muslim Jawa dari abad 7-14 M sangat minim. Itupun hanya menceritakan tentang muslim pribumi yang pasif. Sementara pada masa walisongo (abad 14-16 M), dalam rentang waktu yang relatif lebih singkat mampu mengubah jumlah muslim yang minoritas menjadi mayoritas. Jadi, dalam sejarah penyebaran Islam pra walisongo tersebut muncul ketidakseimbangan antara harapan dankenyataan/ realitas. Penyebaran Islam pra walisongo sudah menghabiskan waktu yang sangat lama sehingga harapannya adalah menghasilkan perkembangan kuantitas dan kualitas masyarakat muslim yang signifikan. Namun kenyataannya hal itu tidak terwujud karena penyebaran Islam tersebut kurang berhasil baik secara kuantitas maupun kualitas.
\end{abstract}

Key word: das sein, das sollen, Islam pra-walisongo 


\section{A. Pendahuluan}

Kata das sein dan das sollen, keduanya diambil dari bahasa Jerman. Das sein berarti keadaan yang sebenarnya (realitas) sedangkan das sollen berarti apa yang dicita-citakan, apa yang diharapkan. Kedua istilah tersebut digunakan sebagai judul tulisan ini karena penulis tertarik ingin mengkaji: (a) Bagaimana realitas penyebaran Islam pra walisongo?; (b) Faktor yang menyebabkan kesenjangan antara data tentang penyebaran Islam pra walisongo dengan hasil perkembangan Islam setelah dilakukan penyebaran tersebut? serta; (c) Implikasi etis yang bisa dipetik dari persoalan ini?

Ketiga pertanyaan tersebut memang bernuansa filsafat ilmu, karena mengarah pada nuansa ontologis, epistemologis dan aksiologis. Problemnya adalah bahwa penulis tidak hanya membutuhkanfilsafat ilmu tetapi juga membutuhkan filsafat sejarahuntuk menggali informasi dari data yang minim. Oleh karena itu digunakanlah paradigma holistik, bukan binner yang mengakomodir penggunaan dua teori atau lebih untuk mendapatkan satu pemahaman yang utuh.

Filsafat sejarah adalah teori yang berusaha memberikan jawaban terhadap pertanyaan mengenai makna dari suatu proses peristiwa sejarah. Dalam suatu peristiwa sejarah, terdapat banyak makna yang tersirat maupun tersurat yang harus diungkap secara jelas agar tidak terjadi kesalahan dalam penafsiran.F.R. Ankersmit menyatakan bahwa secara metodologis filsafat sejarah merupakan teori yang dapat dimanfaatkan oleh penulis sejarah untuk menemukan struktur dasar/ hakikat yang bisa menjadi benang merah antara data yang satu dengan yang lainnya. Pandangan ini lalu memunculkan lahirnya filsafat sejarah spekulatif atau teori sejarah dan filsafat sejarah kritis (F.R. Ankersmit dalam Facione, 2000, 1998).

Dengan pemahaman filsafat sejarah spekulatif yang memandang sejarah sebagai suatu tahapan universal (R.Z Leirrisa, 1996), maka penyebaran Islam pra walisongo dapat dipahami sebagai tahap awal yang disempurnakan oleh masa walisongo.Atau dengan kata lain bahwa penyebaran Islam masa pra walisongo tidak akan terlihat jika tidak dibandingkan dengan penyebaran Islam masa walisongo. Penyebaran Islam pada masa walisongo hanya membutuhkan waktu sekitar 1 hingga 2 abad untuk mengubah jumlah masyarakat muslim dari minoritas menjadi mayoritas, sementara penyebaran Islam pra walisongo selama kurang lebih 7 abad belum bisa membuat orang-orang pribumi yang telah muslim untuk aktif di masyarakat. Adapun berdasarkan pemahaman filsafat sejarah kritis yang memandang bahwa sarana-sarana (seperti metodologi, pendekatan, 
metode, prosedur, aturan, kaidah, dan sebagainya) dapat digunakan untuk mengkaji sebab-sebab terjadinya suatu peristiwa sejarah (Facione, 2000, 1998), maka penulis memanfaatkannya untuk menganalisa data peristiwa sejarah terkait sebab-sebab terjadinya das sein maupun das sollen

\section{B. Das Sein, Realitas Penyebaran Islam Pra Walisongo}

Istilah das sein (Jerman: ['da:zain]) dipopulerkan oleh filsuf fenomenologi dari Jerman, Martin Heidegger (1889-1976) dalam karya besarnya Being and Time, yang secara umum merupakan terjemahan dari ada. Oleh karena itu pembahasan tentang das sein dapat dikatakan sebagai pembahasan yang bernuansa ontologis. Ontologi merupakan salah satu kajian kefilsafatan yang paling kuno danberasal dariYunani.Studi tersebut membahas keberadaan sesuatu yang bersifat konkret.

\section{Das Sein Penyebaran Islam Abad $7 \mathrm{M}$}

Teori yang pertama menyatakan bahwa penyebaran Islam di Jawa sudah dimulai sejak abad $7 \mathrm{M}$. Jika teori ini benar terjadi, berarti keislaman masyarakat Jawa sudah dimulai sejak periode klasik awal atau pada masa kemajuan, tepatnya seiring masa Khulafaur Rasyidin hingga masa dinasti Umayyah.

Dari aspek das sein, penyebaran Islam di Jawa pada abad 7-12 M memang bisa menjadi suatu keniscayaan karena berdasarkan informasi seorang ulama Mesir kepada sejarahwan Sunda, Ir. H. Dudung Fathirrohman pada tahun 2000 - an, dikatakan bahwa salah satu panglima yang membantu Khulafaur Rasyidin terakhir, yaitu khalifah Ali bin Abi Thalib (656-661M) dalam penaklukkan Cyprus, Tripoli dan Afrika Utara berasal dari Timur Jauh (sebutan untuk negara-negara di wilayah Asia termasuk Indonesia). Panglima tersebut juga ikut membangun perluasan kekuasaan Muslim di Iran, Afghanistan dan Sind (644- 650 M).

Informasi ini relevan dengan folklore yang berkembang di tengah masyarakat Sunda, khususnya dalam naskah kuno Pangeran Wangsakerta. Dikatakan bahwa seorang pangeran dari kerajaan Tarumanegara yang bernama Rakeyan Sancang (1.591 M) pernah membantu Imam Ali dalam beberapa pertempuran di Timur Tengah. Jadi tidak diragukan lagi bahwa panglima yang disebut oleh tokoh dari Mesir di atas adalah Rakeyan Sancang.

Rakeyan Sancang adalah putra kandung raja Taruma negara ke VIII Kertawarman (561-628 M) dari istri di luar kerajaan yang tinggal di hutan Sancang. Menurut Salaka, sebagaimana dikutip Samantho (2012), 
keislaman beliau diawali ketika khalifah Utsman bin Affan (644-657 M) mengirim utusanya ke Cina untuk mengenalkan Islam. Utusan yang tidak lain adalah Mu'awiyah bin Abu Sofyan, yang kemudian singgah di Jawa. Itulah sebabnya teori penyebaran Islam pada abad ke $7 \mathrm{M}$ ini dikatakan terkait dengan teori Arab karena Arab merupakan daerah asal khalifah Utsman dan Mu'awiyah. Wilayah pesisir utara yang menjadi tempat singgah rombongan Mu'awiyah adalah wilayah kerajaan Tarumanegara, sehingga wajar jika rombongan tersebut berinteraksi dengan bangsawan Tarumanegara. Mu'awiyah akhirnya berhasil mengislamkan beberapa bangsawan Jawa, termasuk Rakeyan Sancang dari Tarumanegara dan raja Jay Shima, putra Ratu Shima dari Kalingga (Salaka, sebagaimana dikutip Samantho, November, 22, 2012).

Sejarah penyebaran Islam di Jawa pada abad $7 \mathrm{M}$ tersebut dapat dikaitkan dengan proses penyebaran Islam di Sumatera pada masa yang sama, yaitu:

a. Para penulis Tiongkok, antara lain I-Tsing (634-713 M) mencatat bahwa pada abad $7 \mathrm{M}$ telah ada penyebaran Islam di Nusantara dari Sumatera kemudian ke Jawa dan berbagai wilayah lainnya (Yamin, 1956: 7).

b. Sebagaimana dikutip Azra (2013: 24) I-Tsing mencatat bahwa di Sumatera terdapat pelabuhan bernama Muara Sungai Bhoga (Sribhoga atau Sribuza) yang terletak di Muara Sungai Musi. Pelabuhan itu kelak lebih kenal dengan Pa-lin-fong (Palembang), ibukota Sriwijaya. Segmen tertentu penduduk sekitar Muara Sungai Bhoga telah berinteraksi dengan muslim Timur Tengah pada abad $7 \mathrm{M}$; dan dalam batas tertentu sudah mengenal Islam sehingga nama mereka saat itu sudah ke Arabaraban. Contohnya banyak laki-laki yang memiliki nama depan Abu (Azra, 2013: 25).

c. Catatan I-Tsing tersebut senada dengan peta penyebaran Islam yang menginformasikan bahwa sekitar tahun $625 \mathrm{M}$, sudah ada perkampungan Arab Islam di Barus, pesisir Sumatera.Akan tetapi, peta tersebut perlu dikritisi bahwa judul "Peta Penyebaran Islam abad 1-16 M" kurang tepat karena nabi Muhammad sebagai pembawa agama Islam baru lahir pada abad 7 Masehi. 


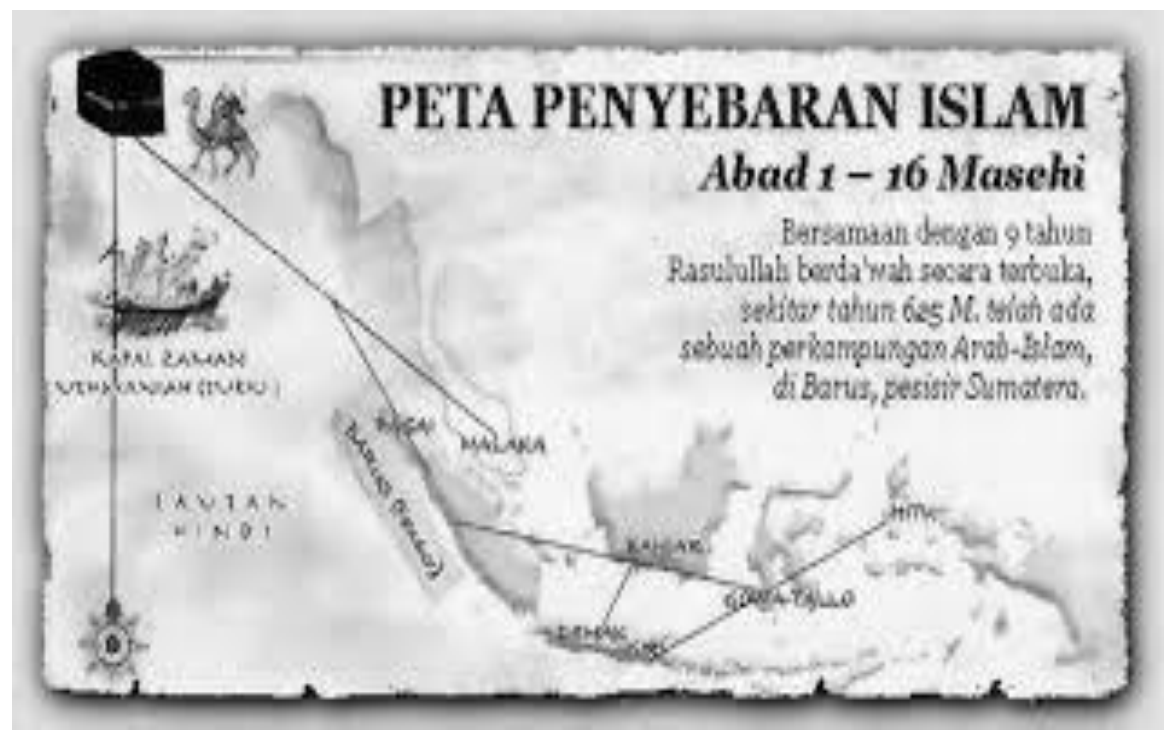

Gambar1. Peta penyebaran Islam di Nusantara pada abad 7 M (Sumber: Istimewa)

d. Selanjutnya, penyebaran Islam dari Sumatera ke Jawa memiliki kronologi sebagai berikut: Pertama, menurut Yamin (1956: 7), konon Sriwijaya menguasai Melayu (Jambi) yang sudah mengenal Islam terlebih dahulu (689-692 M). Kedua, mengutip Moens (TBG 1937) dari Yamin (1957: 8) dikatakan bahwa setelah beberapa waktu kerajaan Sriwijaya berdiri, pusat pemerintahannya kemudian berpindah dari Kelantan ke Muara Takus (Jambi). Setelah itu kekuasaan Sriwijaya terus meluas hingga tanah Jawa, termasuk Ta-lo-mo (Tarumanegara). Ketiga, adapun Cho-po Holing (Kalingga), meskipun bukan taklukan Sriwijaya, namun memiliki hubungan baik dengan Tarumanegara sehingga wajar jika pengaruh Islam di Tarumanegara turut menyebar ke Kalingga.

e. Perlu diketahui, bahwa sejak abad $4 \mathrm{M}$, kerajaan Tarumanegara telah muncul sebagai kerajaan Hindu-Buddha di Jawa Barat. Setelah itu pada abad 6 M menyusul Kalingga sebagai kerajaan Hindu di Jawa Tengah. Jadi, saat Rakeyan Sancangdan Jay Shima masuk Islam pada abad 7 M, kerajaan mereka adalah kerajaan Hindu-Buddha yang kuat. Oleh karena itu keislaman keduanya adalah hal yang luar biasa. Penyebaran Islam dikedua kerajaan tersebut melebihi wilayah Jawa lainnya, karena penyebaran Islam di Jawa rata-rata terjadi pada abad $15 \mathrm{M}$. 


\section{Das Sein Penyebaran Islam Abad 11 M}

Teori initerkait dengan penemuan nisan Fatimah binti Maimun di desa Leran, Gresik, Jawa Timur. Berdasarkan keterangan dalam nisannya, ia wafat pada hari Jumat, 7 Rajab $475 \mathrm{H}$ atau 2 Desember $1082 \mathrm{M}$. Hal yang menarik adalah bahwa tulisan pada nisan Fatimah binti Maimun ternyata menggunakan kaligrafi kuffi, sebuah model kaligrafi dari Kuffah. Gaya penulisan tersebut ternyata juga ditemukan pada nisan yang ditemukan di Phanrang, Champa Selatan. Dengan adanya fenomena nissan berkaligrafi kuffi ini menunjukkan bahwa Nusantara, khususnya Giri, telah menjadi bagian dari tempat persinggahan para pedagang muslim yang memiliki jalur perdagangan internasional dari bagian selatan Cina, India, hinggaTimur Tengah (Simon, 2007: 43).

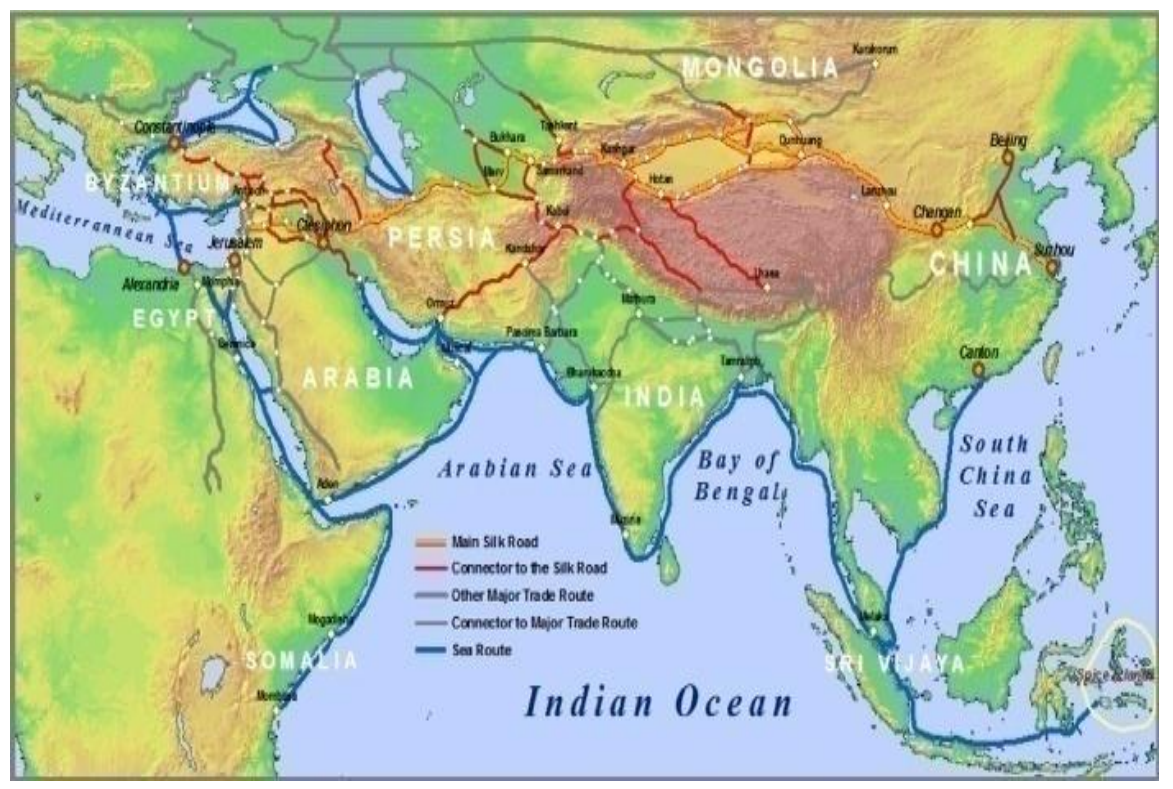

Gambar 2.Jalur perdagangan masyarakat muslim abad $11 \mathrm{M}$ yang membentang dari Arab, India bagian selatan China

(Sumber: Istimewa)

\section{Das Sein Penyebaran Islam Abad 12-14 M}

Teori yang ketiga adalah teori abad 12-14 M, yang terkait dengan kedatangan pedagang Gujarat ke Nusantara. Menurut J.Pijnapel, orang Arab bermazhab Syafi'i telah bermukim di Gujarat dan Malabar sejak abad VII M. 
Lebih lanjut ia katakan bahwa penyebaran Islam di Indonesia tidak langsung dilakukan pedagang Arab, melainkan oleh pedagang Gujarat yang telah memeluk Islam, kemudian berdagang di Indonesia. Selanjutnya, Snouck Hurgronje dalam L'arabie et Les Indes Neerlandaises, sebagaimana dikutip wikipedia, juga menjelaskan bahwa Islam masuk ke Indonesia melalui kota-kota di anak benua India seperti Gujarat, Bengali, dan Malabar karena Islam terlebih dahulu berkembang di kota tersebut.

Ia mengatakan bahwa penyebaran Islam pertama di Indonesia terkait teori Gujarat karena didasarkan pada peranan orang-orang Gujarat yang telah membuka hubungan dagang dengan Indonesia sebelum pedagang Arab. Lalu berdasarkan informasi dari wikipedia yang mengutip penjelasan Wirjosuparto menyebutkan tentang dasar bukti teori Gujarat adalah: Pertama, corak batu nisan Sultan Malik as-Saleh dan Maulana Malik Ibrahim memiliki kemiripan dengan corak nisan yang ada di Gujarat; Kedua, hubungan dagang Indonesia dengan India telah lama terjalin, melalui jalur perdagangan Indonesia - Cambay - Timur Tengah - Eropa.

Dalam perkembangannya, teori Gujarat dibantah oleh banyak ahli. Mereka mengatakan bahwa Islam masuk Indonesia bukan dibawa pedagang Gujarat, karena pada abad 12-13 M wilayah Gujarat masih dikuasai Hindu. Azra menjelaskan bahwa Gujarat hanya tempat persinggahan pedagang Arab sebelum melanjutkan perjalanan ke Asia Tenggara dan Asia Timur. Jadi teori yang benar menurut Azra adalah bahwa Islam masuk ke Indonesia dibawa oleh orang Arab.

Benang merah dari pro kontra teori Gujarat terdapat dalam penjelasan Ibn Bathuthah pada kitabnya yang berjudul el Khuzm, tentang eksistensi pedagang Gujarat di Jawa pada abad $14 \mathrm{M}$, atau pada masa pemerintahan Majapahit. Eksistensi mereka dianggap sebagai kesinambungan dari eksistensi para pendahulunya yang telah datang ke Nusantara pada abad 12-13 M. Jadi, dapat disimpulkan bahwa pada abad 12-13 M memang sudah ada pedagang Gujarat muslim yang sampai di Nusantara. Meski demikian, eksistensi mereka tidak lepas dari pengaruh bangsa Arab.

Istilah Arab kemudian menjadi bermakna umum karena digunakan untuk menyebut pemerintahan Islam di sekitar Timur Tengah yang belum tentudipimpin oleh orang Arab. Contohnya adalah pemerintahan Turki Usmani yang berdiri sejak tahun $1300 \mathrm{M}$ atau abad 13/ $14 \mathrm{M}$.

Perlu diketahui bahwa pemerintahan Turki Usmani didirikan oleh bangsa Turki dari kabilah Oghuz yang mendiami daerah Mongol dan daerah utara negeri China. Disebut sebagai kaum Osmanli oleh bangsa Turki sesuai dengan nama pendirinya yang bernama Osman I (Ar.: 
Utsman/ Usman I) yang memproklamirkan diri sebagai Padisyah al-Usman atau raja besar keluarga Usman tahun 1300 M (699 H). Kerajaan yang didirikan oleh Usmani ini selanjutnya memperluas wilayahnya ke bagian Benua Eropa. Ia menyerang daerah perbatasan Bizantium dan menaklukkan kota Broessa tahun 1317 M sehingga tahun 1326 M dijadikan sebagai ibukota negara. Akhirnya dinasti Usmaniyah berhasil menciptakan sebuah negara yang luas, mencakup seluruh Eropa Tenggara (yang semula di bawah kekuasaan dinasti Umayyah) sampai perbatasan utara Honaria, Anatolia dan Timur Tengah hingga perbatasan Iran, serta pantai Mediterania di Afrika Utara hingga hampir Samudera Atlantik (Esposito, Jilid 6, 2002: 129).

Terkait dengan penjelasan Ibn Bathuthah tentang eksistensi pedagang Gujarat di Jawa pada abad $14 \mathrm{M}$, mereka melaporkan kepada penguasa Turki saat itu, yaitu Sultan Mahmud I (1394-1421 M) bahwa mereka melihat adanya komunitas muslim Jawa di tengah masyarakat Hindu, namun mereka sangat pasif. Sang Sultan sangat prihatin sehingga beliau meminta para amir untuk mengirim delegasi masing-masing sebagai tim juru dakwah yang akan dikirim ke tanah Jawa. Tim itulah kelak yang dikenal dengan sebutan walisongo.

Kata "wali" berasal dari kata Arab "aulia" yang berarti penolong. Sedangkan kata "sanga" memiliki beberapa makna, yaitu:

a. bermakna sembilan, itulah sebabnya muncul pendapat bahwa seluruh wali berjumlah sembilan. Pendapat ini tidak mengakomodir semua wali periode pertama karena yang dikatakan sebagai walisongo tersebut adalah: Sunan Gresik; Sunan Ampel; Sunan Bonang, Sunan Drajat, Sunan Kudus, Sunan Giri, Sunan Kalijaga, Sunan Muria serta Sunan Gunung Jati;

b. bermakna mulia, karena kata songo/ sanga diperkirakan berasal dari kata tsana yang dalam bahasa Arab berarti mulia. Jadi walisongo berarti wali yang mulia;

c. bermakna tempat, karena kata songo/ sanga diperkirakan berasal dari kata dalam bahasa Jawa sana yang berarti tempat. Jadi walisongo adalah para wali yang menetap di suatu tempat;

d. bermakna sembilan, namun bukan dalam konteks jumlah keseluruhan melainkan jumlah setiap periode. Dalam tulisan ini, penulis lebih mengikuti pendapat yang terakhir. Oleh karena itu dalam pandangan penulis, tim juru dakwah yang dibentuk oleh Sultan Mahmud I adalah para walisongo periode pertama. Setelah itu akan muncul tim walisongo yang lain pada periode-periode selanjutnya. 


\section{Kesenjangan Antara Realitas dan Harapan (Das Sollen)}

Untuk memahami penyebaran Islam pra walisongo sebagai das sollen, bisa dibandingkan dengan klasifikasi sejarah perkembangan peradaban Islam secara umum yang disampaikan oleh Harun Nasution dalam bukunya yang berjudul Islam Ditinjau Dari Berbagai Aspeknya, (UI, Jakarta Press, 2008: 50). Ia membagi klasifikasi tersebut menjadi tiga periode, yaitu periode klasik (650 -1250 M), periode pertengahan (12501800 M) dan periode modern (1800-sekarang).Periode klasik dibagi menjadi dua masa, yaitu masa kemajuan dan masa disintegrasi. Masa kemajuan Islam dimulai dari tahun 650-1000 M, sedangkan masa disintegrasi dimulai sejak tahun $1000 \mathrm{M}-1250 \mathrm{M}$. Jadi kalau teori penyebaran Islam pra walisongo terjadi sejak abad 7-14 M berarti seiring dengan perkembangan periode klasik hingga pertengahan.

\section{Das Sollen Perkembangan Islam Abad $7 \mathrm{M}$}

Teori penyebaran Islam di Jawa pada abad $7 \mathrm{M}$ seiring dengan periode klasik perkembangan peradaban Islam secara umum, khususnya pada masa kemajuan. Masa tersebut dikatakan sebagai masa kemajuan karena pada tahun $661 \mathrm{M}$ wilayah Islam di Arab telah meluas hingga Mesir, Suriah, Irak dan sebagian besar Iran. Setelah itu dinasti Umayyah terus memperluas wilayahnya ke arah Barat melewati Afrika Utara hingga mencapai Atlantik. Pada tahun 711 (abad 8 M) mereka menyeberang ke Spanyol dan dengan cepat menaklukkan sebagian besar negeri itu. Ke arah Timur, dinasti Umayyah menguasai Iran hingga Asia Tengah (Bukhara dan Samarkand) serta ke India di Barat Laut (Esposito, Jilid 6, 2002: 98).

Hasil penyebaran Islam dari Arab ke berbagai wilayah tersebut menghasilkan beberapa kota yang menjadi ikon peradaban Islam saat itu. Hal itu antara lain terjadi di Cordoba dan Granada yang diilustrasikan sebagai berikut:

Cordoba merupakan ibukota Andalus sejak masa Abdurrahman III dari Bani Umayyah.Pada malam hari kota ini diterangi cahaya lampu sepanjang sepuluh mil tanpa terputus. Loronglorong dialasi dengan batu ubin. Sampah-sampah disingkirkan dari jalan-jalan. Masyarakat di situ semuanya terpelajar. Di pinggiran kota bagian timur terdapat 170 wanita penulis mushaf dengan khat kufi. Ada lima puluh rumah sakit dan delapan puluh sekolah. Orang-orang miskin menuntut ilmu gratis. Adapun masjidnya sampai sekarang masih berdiri megah dengan ditopang 1093 marmer berbentuk papan catur. 
Demikian pula istana az Zahra yang memiliki nilai seni yang tak ternilai harganya. Lalu Granada, kota ini memiliki istana alHambra yang menakjubkan sehingga penyair Perancis, Victor Hugo menggambarkannya seperti dihias oleh malaikat. Tidak kalah menakjubkan juga kota-kota seperti Sevilla, Baghdad dan Damaskus. Kota-kota muslim tersebut berkembang pesat jauh melampaui wilayah non muslim di sekitarnya. Hal itu sebagaimana disampaikan Lavis dan Rambou dalam buku Sejarah Umum yang menyatakan bahwa masyarakat Eropa di luar pemerintahan Islam pada abad 7-10 M masih terbelakang. Eropa masih penuh hutan belantara dan sistem pertaniannya masih buruk. Rumah-rumah di Paris dan London dibangun dari kayu dan tanah yang dicampur dengan jerami dan bambu. Rumah-rumah itu tidak berventilasi dan tidak punya kamar yang teratur. Mereka juga tidak mengenal kebersihan karena sampah dapur dibuang di depan rumah.

Sayangnya masa kemajuan tersebut tidak berlaku pada masa penyebaran Islam abad $7 \mathrm{M}$ di Jawa. Meskipun dikatakan telah berhasil mengislamkan dua tokoh dari elit politik (priyayi) Jawa, yaitu Rakeyan Sancang dan Pangeran Jay Shima, akan tetapi hingga 6 abad kemudian, penyebaran Islam tersebut belum mampu menghasilkan perkembangan kualitas dan kuantitas masyarakat muslim yang signifikan, bahkan belum mampu untuk sekedar memunculkan kota tertentu yang menjadi bukti perkembangan eksistensi mereka.

\section{Das Sollen Perkembangan Islam Abad $11 \mathrm{M}$}

Teori penyebaran Islam di Jawa pada abad $11 \mathrm{M}$ bertepatan dengan periode klasik sejarah perkembangan peradaban Islam, tepatnya pada masa disintegrasi yang dimulai sejak tahun 1000 M -1250 M. Pada masa disintegrasi ini, kekhalifahan Bani Umayyah di Eropa mengalami keruntuhan akibat kekalahan mereka di periode awal Perang Salib (sekitar 1094-1156 M) (Esposito, Jilid 3, 2002: 2).

Keruntuhan kekhalifahan Bani Umayyah merupakan simbol dari keruntuhan otoritas Sunni. Maka wajar jika setelah keruntuhannya, muncul beberapa kekuatan dari kalangan Syi'ah yang mendirikan negara-negara 
kecil sendiri, seperti dinasti Fathimiyah di Mesir (909-1171 M) dan Buwaihiyah (945-1055) di Irak (Esposito, Jld 2, 2002: 43-44). ${ }^{1}$

Jika Fatimah binti Maimun dan rombongannya adalah kelompok yang mampu eksis pada masa disintegrasi, maka dapat diperkirakan bahwa mereka adalah bagian dari kelompok Syi'ah. Apalagi didukung dengan adanya kaligrafi kuffi (yang berasal dari Kuffah) pada nissannya. Adanya kaligrafi dari Kuffah tersebut tidak hanya menunjukkan bahwa Jawa adalah bagian dari jalur singgah perdagangan internasional namun juga menunjukkan eksistensi Kuffah sebagai salah satu basis pendukung ahlul bait yang bisa go internasional (Esposito, Jilid 1, 2002:75). Penulisan lafadz al-Qur'an pada masa awal banyak menggunakan kaligrafi kuffi terutama pada arsitektur dan seni dekoratif Islami, termasuk nissan. Setelah abad 13 M penggunaannya terbatas, tetapi potensi desainnya tetap menjadi basis dalam sejumlah karya seniman kontemporer (Esposito, Jilid 2, 2002: 288).

Namun penemuan batu nisan Fatimah binti Maimun tersebut tidak diiringi penemuan bahwa pada masa itu masyarakat pribumi sudah mengenal ajaran Syi'ah karena kemungkinan, para pendatang asing muslim yang singgah di Giri saat itu cenderung bersikap tertutup dalam hal agama kepada penduduk pribumi. Mereka hanya berdakwah di kalangan sendiri. Bisa jadi untuk menghindari konflik dengan kekuasaan pemerintahan yang membawahi Giri saat itu, yaitu pemerintahan Kediri (1045-1221 M), karena pemerintahan tersebutbernuansa Hindu.

\section{Das Sollen Perkembangan Islam Abad 12-14 M}

Teori penyebaran Islam di Jawa pada abad 12-14 M bertepatan dengan periodepertengahan perkembangan peradaban Islam (1250-1800 M). Pada periode ini di wilayah Sumatera sudah ada kerajaan Islam Samudera Pasai sebagai bukti kejayaan Islam di Nusantara. Sementara untuk konteks Jawa, saat itu di bawah pemerintahan kerajaan Majapahit.

Berdasarkan naskah Nagara kertagama atau Desawarnana, 2 diketahui bahwa Majapahit adalah kerajaan di Nusantara yang paling

${ }^{1}$ Perseteruan antara Sunni dan Syiah sebenarnya diawali dari persoalan politik yang kemudian berkembang menjadi ideologi. Pada awalnya, semua umat Islam adalah kaum Sunni (pendukung sunnah Rasul). Nama Syi'ah kemudian disematkan kepada kelompok yang mengkultuskan ahl bait dan keturunan sebagai pemimpin paling sah setelah wafatnya Rasulullah. Sejak masa Abu Bakar hingga masa pemerintahan Bani Umayyah para pendukung ahl bait tersebut muncul sebagai kelompok oposisi. Maka wajar, begitu dinasti Umayyah runtuh maka kelompok-kelompok berhaluan Syi'ah segera mendirikan dinasti masing-masing. 
berhasil dalam mempersatukan daerah-daerahdari daratan Asia Tenggara di sebelah barat, hingga Irian Jaya (Koentjaraningrat, 1984: 46). Kekuasaan Majapahit mencapai puncaknya pada masa Hayam Wuruk (1350-1389 M).

Dalam naskahNagarakrtagamatersebutdijelaskan tentang Hayam Wuruk sebagai pria muda yang sangat menarik dan lincah. Selain itu, dijelaskan pula tentang raja-raja yang berkuasa sebelum Hayam Wuruk. Semua informasi diberi data lengkap mengenai tahun pendirian serta peristiwa di sekitarnya sehingga dapat dicocokkan dengan prasasti yang telah ditemukan (Sedyawati, 2001: 259). Dari informasi tersebut akhirnya diketahui bahwa Majapahit didirikan oleh Raden Wijaya (1294-1309 M) di kota Mojokerto sekarang. Penggantinya secara berturut-turut adalah putra beliau yang bernama Jayanegara (1309-1328 M), lalu putri beliau yang bernama Tribhuana Wijayatunggadewi/ Bhre Kahuripan (1328-1350 M). Setelah itu barulah Rajasanegara/ Hayam Wuruk.

Samudera Pasai, berdiri seiring berdirinya Majapahit (abad 13 M). Pendirinya adalah Marah Silu yang bergelar Sultan Malik as-Saleh. Dari nisannya diketahui bahwa beliau wafat pada tahun 696 H/ 1297 M. Setelah itu wilayah Pasai meluas menjadi SamuderaPasai. Sejarah Samudera Pasai antara lain berdasarkan Hikayat Raja-raja Pasaiserta catatan Marco Polo (1293). Berdasarkan sumber tersebut diketahui bahwa nama Samudera Pasai merupakan gabungan dari Samudera (Samara) yang terletak agak jauh dari laut dan Pasai (Psangan/ Basma) yang terletak di pesisir utara Aceh.3 Dalam Rihlah ila l-Masyriq (Pengembaraan ke Timur), Ibn Batuthah (1304-1368) mencatat bahwa beliau pernah berkunjung ke Samudera Pasai pada tahun 1345 M (Yamin, 1956: 14).

Penaklukan Samudera Pasai oleh Majapahit (1339 M)terjadi pada masa Tribhuana Wijaya Tunggadewi. Penaklukan dipimpin oleh maha patih Gajah Mada. Meski sebagai kerajaan taklukan Majapahit, akan tetapi Samudera Pasai tetap berkembang dengan baik dan menjalin kerja sama dengan beberapa kerajaan manca. Pada tahun 1350 M, di masa awal pemerintahan Hayam Wuruk, Samudera Pasai berhasil menjalin hubungan dengan Malaka.Menurut Ma Huan dan Tomé Pires, hubungan itu bisa terjalin karena kondisi sosial budaya keduanya mirip. Lalu, sebagaimana diceritakan dalam Sulatus Salatin, hubungan itu semakin erat karena

${ }^{2}$ Arti Nagarakrtagama adalah perjalanan yang dilakukan (di dalam wilayah kerajaan Majapahit) oleh Hayam Wuruk, sedangkan Desawarnana berarti penggambaran tentang daerah.

${ }^{3}$ Marco Polo juga mencatat wilayah muslim lainnya di pantai utara Aceh, yaitu Lamuri (Lambri) dan Perlak (Ferlec). 
pernikahan putri Pasai dengan raja Malaka. Dari Malaka, Islam disebarkan ke Brunai, Mindanao, kepulauan Sulu; Tanjungpura (Kal-Sel), hingga Jawa.

Bukti bahwa pada masa Majapahit telah ada komunitas muslim, didukung adanya penemuan koin-koin uang logam bertuliskan lafadz la ilaahaillallah beberapa waktu lalu. Koin tersebut ditemukan bersama-sama koin-koin uang logam Tiongkok dan beberapa barang dari zaman Majapahit. Sebagaimana penjelasan atas ditemukannya 60 ribu keping uang logam Tiongkok yang menunjukkan adanya hubungan dagang Majapahit dengan Tiongkok, maka penemuan koin berlafadz la ilaahaillallah tersebut juga menunjukkan bahwa sudah ada hubungan yang baik antara pemerintah Majapahit dengan pemerintah Arab (baca: Turki Usmani).

Sebagai sesama warga masyarakat di wilayah Nusantara bahkan sesama warga Majapahit, idealnya perkembangan masyarakat muslim di Jawa pada masa itu juga tidak jauh berbeda dengan Samudera Pasai. Sayangnya hal yang terjadi tidak demikian, karena posisi mereka di pusat kerajaan Majapahit membuat mereka sulit melepaskan diri dari unsurunsur klasifikasi simbolik yang mempengaruhi masyarakat Jawa.

\section{Implikasi Etis}

Implikasi etis dari kesenjangan antara das sein dan das sollen penyebaran Islam masa pra walisongo dapat dilihat dari perbandingannya dengan masa walisongo sebagai berikut:

\section{Pentingnya Observasidan Follow up terhadap Persoalan Masyarakat}

Dengan adanya kisah yang menyebabkan dibentuknya walisongo sebagai tim dakwah di pulau Jawa, membuktikan bahwa dakwah pada masa walisongo diawali dengan observasi yang matang. Meskipun sebelum para pedagang Gujarat membuat laporan kepada Sultan Mahmud I, para pedagang asing juga sudah datang silih berganti ke Jawa, akan tetapi masing-masing tidak saling terkait, sehingga dapat dikatakan bahwa observasi dan follow up persoalan dakwah tidak ada pada masa pra walisongo. Kalaupun ada observasi, hal itu lebih terkait dengan persoalan dagang, sehingga misi dagang mereka lebih berhasil dibanding misi dakwahnya.

Bukti keseriusan follow up atas laporan para pedagang Gujarat tentang kepasifan masyarakat muslim Jawa adalah perintah Sultan Mahmud I kepada para amir (gubernur) untuk mengirimkan delegasi 
masing-masing sebagai anggota tim dakwah yang akan dikirimkan ke Jawa. Mereka bukan pedagang yang mendapat tugas tambahan, melainkan murni sebagai juru dakwah yang akan mendampingi masyarakat Jawa untuk mengatasi kepasifannya. Karena kepasifan masyarakat tersebut disebabkan oleh berbagai persoalan yang kompleks, maka mereka tidak hanya akan tinggal di Jawa untuk sementara waktu melainkan untuk waktu yang lama bahkan hingga akhir hayatnya. Pembentukan tim seperti ini belum pernah dilakukan pada masa pra walisongo.

\section{Pentingnya Prioritas Kegiatandan Intensitas Pendampingan}

Penyebaran Islam pada masa pra walisongo dilakukan oleh para pedagang. Hal itu berlaku baik pada masa penyebaran Islam abad 7, 11, 12 maupun 14 M. Sebagai pedagang, maka prioritas kegiatan mereka tentu saja berdagang, sedangkan dakwah Islamiyah merupakan kegiatan tambahan di sela-sela kegiatan utama mereka. Itulah sebabnya setelah Rakeyan Sancang dan Jay Shima menyatakan masuk Islam, rombongan Mu'awiyah tidak melanjutkan dakwah lagi kepada para priyayi lain maupun masyarakat yang ada di sekitar, karena mereka harus segera melanjutkan perjalanan berdagang ke wilayah lain. Berbeda dengan para walisongo, prioritas kegiatan mereka memang sebagai juru dakwah sehingga mereka akan melakukan pendampingan secara total sehingga mereka perlu menetap dalam suatu wilayah dalam waktu lama, bahkan hingga akhir hayatnya.

Para pedagang muslim pra walisongo juga biasa berpindah-pindah dari negeri satu ke negeri yang lain. Mereka tidak memiliki waktu untuk mendampingi masyarakat secara intensif. Oleh karena itu sepeninggal mereka dari Jawa tidak ada kader dari masyarakat pribumi yang bisa meneruskan dakwahnya. Berbeda dengan para walisongo, mereka mendirikan banyak pesantren sehingga dapat dimanfaatkan untuk mendidik kader dakwah dari kalangan masyarakat muslim pribumi. Penyebaran Islam di Jawa pada abad $7 \mathrm{M}$ memang sudah bagus karena sudah berhasil mengislamkan keluarga raja. Jika dilakukan secara intensif, hal ini bisa mempermudah dakwah selanjutnya di kalangan rakyat biasa karena biasanya apa yang dilakukan oleh keluarga raja akan diikuti oleh rakyatnya. Sayangnya dakwah yang dilakukan pada masa itu tidak intensif, terbukti tidak ditemukan data keislaman masyarakat Jawa setelah masuk Islamnya Rakeyan Sancang dan Pangeran Jay Shima. 


\section{Pentingnya Strategi Dakwah}

Saat para pedagang muslim datang ke tanah Jawa, masyarakat yang mereka hadapi sudah memiliki local wisdom yang mapan. Idealnya, mereka membutuhkan strategi khusus supaya dakwah mereka berhasil. Namun tidak jarang para pedagang tersebut justru menjaga jarak dengan pribumi untuk menghindari konflik. Dampak dari dakwah yang cenderung tanpa strategi tersebut menyebabkan masyarakat pribumi tetap merasa asing dengan Islam dan kurang mantap untuk memeluknyameski mereka telah menyadari eksistensi agama tersebut sejak berabad silam. Akhirnya sebagian besar dari mereka tetap memilih agama resmi kerajaan.Sementara masyarakat pribumi yang telah muslim cenderung bersikap pasif karena selain telah menjadi out of group bagi masyarakat lain, pengetahuan keislaman mereka juga minim. Dengan demikian, hasil pengamatan para pedagang Gujarat di abad $14 \mathrm{M}$ tentang kondisi masyarakat muslim pribumi yang pasif, merupakan closing statement yang menunjukkan bahwa penyebaran Islam pra walisongo tidak maksimal karena tidak menghasilkan perkembangan Islam yang signifikan, baik secara kualitas maupun kuantitas. 4

Berbeda dengan masa walisongo. Sejak awal mereka memang telah dipersiapkan untuk menghadapi masyarakat Jawa yang memiliki persoalan yang kompleks. Oleh karena itu sejakperiode pertama mereka tidak hanya sebagai tim yang terdiri dari ahli agama saja melainkan juga ahli di bidang umum. Tim tersebut diketuai oleh Maulana Malik Ibrahim (w.1419 M) atau Sunan Gresik.Beliau berasal dari Turki. Ahli tata negara. Adapun anggota timnya adalah: (1) Maulana Ishaq, berasal dari Samarkand dekat BukharaUzbekistan/ Rusia. Ahli pengobatan. (2) Syekh Jumadil Kubro, berasal dari Mesir. Ahli agama. (3) Maulana Muhammad al-Maghribi (w. 1465 M), berasal dari Maghribi atau Maroko. Ahli agama. (4) Maulana Malik Isroil (w.1435 M), berasal dari Turki. Ahli tata negara/ sosial politik. (5) Maulana Muhamad Ali Akbar (w.1435 M) berasal dari Persia/ Iran. Beliau ahli pengobatan. (6) MaulanaHasanuddin (w.1462 M), berasal dari Palestina. Ahli agama. (7) MaulanaAliyuddin (w.1462 M), berasal dari Palestina. Ahli

${ }^{4}$ Perkembangan dari segi kualitas antara lain dapat dilihat dari kemajuan pembangunan di wilayah setempat seperti di Cordoba, Granada, Baghdad, Damaskus dan Sevilla. Adapun perkembangan dari segi kuantitas dapat dilihat dari pertambahan jumlah penduduk muslimnya. Tidak ada data yang membuktikan bahwa kuantitas komunitas muslim pra walisongo semakin bertambah seiring pertambahan waktu yang ada. Itulah sebabnya kualitas mereka juga rendah karena masyarakat muslim pribumi yang ada cenderung pasif. 
agama. (8) SyekhSubakhir atau Syaikh Muhammad al-Baqir, berasal dari Persia. Beliau ahli rukyah.5

Berdasarkan komposisi tersebut terlihat jelas bahwa para wali menekankan pentingnya menerapkan kesatuan ilmu (unity of sciences/ UoS) atau paradigma holistik sebagai strategi dakwahsehingga lebih fleksibel dalam mengatasi berbagai masalah. Hal ini berbeda dengan masa pra walisongo yang cenderung menerapkan satu ilmu, _yaitu ilmu agama _ atau paradigma binner saja sehingga hanya bisa mengatasi persoalan keagamaan saja.
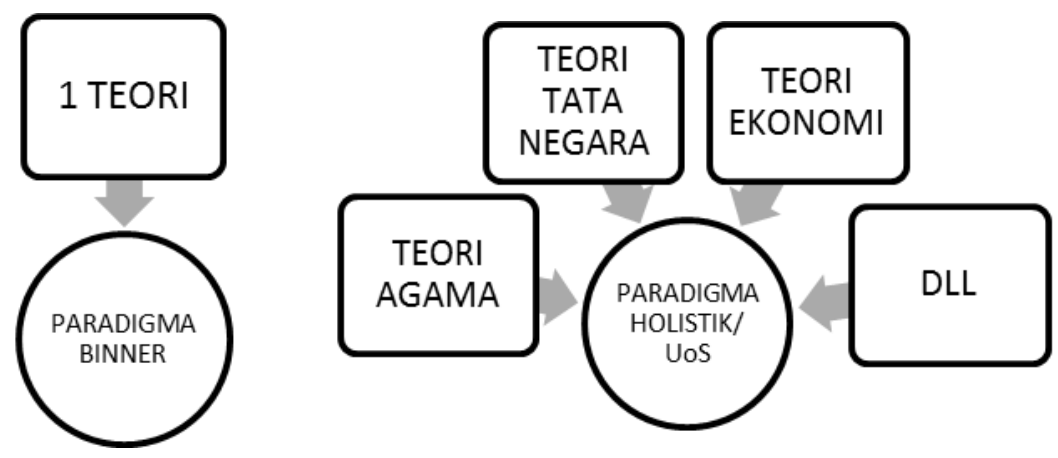

Gambar 3.Perbandingan paradigma binner dengan holistik/ UoS. Paradigma holistik menerapkan kesatuan pengetahuan (UoS) sehingga dapat menyelesaikan persoalan lebih maksimal.

Manfaat penerapan UoS pada masa itu antara lain sebagai berikut:

a. UoS membuat para wali menjadi kreatif dalam mengemas dakwah. Selain mendirikan pesantren, mereka juga berdakwah secara intensif melalui aktifitas sosial, media olah sastra, seni dan budaya. Mereka mengemas olah sastra dan seni sedemikian rupa hingga hasilnya dapat dinikmati oleh semua kalangan, baik sebagai hiburan maupun sebagai wahana pembelajaran. Berhubung masyarakat pribumi menyukai tembang maka naskah-naskah keislaman dari Arab yang semula berbentuk prosa kemudian mereka ubah menjadi bentuk puisi tradisional Jawa. Puisi tersebut ditembangkan. Bagi masyarakat yang melek huruf dapat menggunakannya sebagai sumber tekstual keagamaan. Lalu bagi masyarakat yang masih buta huruf bisa menggali

5Salim Ibrahim, Kisah Walisongo Dilihat dari Beberapa Periode, http://salimibra.blogspot.co.id/2012/12/wali-songo-dari-beberapa-periode.html 
kedalaman makna dari syair yang ditembangkan.Teks dalam tembang tersebut sarat makna karena para wali memasukkan ajaran-ajaran Islam di dalamnya. Hal ini jelas tidak ada pada masa pra walisongo karena tidak ada bukti olah sastra yang dilakukan karena olah sastra Jawa sudah dilakukan sejak abad abad $8 \mathrm{M}$ namun baru muncul olah sastra Islami pada abad $15 \mathrm{M}$, yaitu pada masa walisongo.

b. UoS bisa membuat para wali lebih dekat dengan masyarakat karena mereka tidak hanya menyampaikan ajaran teoritis saja tapi juga melakukan aktifitas sosial sesuai kebutuhan masyarakat. Misalnya Maulana Malik Ibrahim.Sesampainya di Giri, beliau tidak langsung mendirikan pesantren melainkan mengajarkan sistem irigasi terlebih dahulu kepadamasyarakat. Sebab saat itu masyarakat Giri tengah mengalami musim paceklik panjang akibat gagal panen. Beliau juga menjadi tenaga medis cuma-cuma karena banyak wabah penyakit yang menimpa masyarakat miskin. Aktifitas di bidang sosial ini membuat beliau sangat dekat dengan masyarakat sehingga mempermudah beliau untuk mengenalkan ajaran Islam.

c. UoS membuat dakwah lebih efektif dan efisien karena dengan jumlah tim yang relatif sedikit, para wali bisa menerapkan ilmu tata negara untuk mengelola dakwah di seluruh penjuru Jawa. Mereka menerapkan teori sentralisasi untuk memantau dan mengendalikan persoalanpersoalan yang bersifat umum di berbagai wilayah dari wilayah pusat. Dalam hal ini mereka memilih Giri atau Gresik sebagai pusat kegiatan.Untuk itulah ada forum Giri Kedaton sebagai pusat kegiatan olah sastra yang hasilnya akan disebarkan ke seluruh penjuru Jawa bahkan seluruh penjuru Nusantara. Namun untuk persoalan-persoalan yang bersifat khusus untuk wilayah tertentu mereka menerapkan teori desentralisasi.Misalnya, mengutus perwakilan wali untuk menetap di wilayah tertentu. Hal itu tentunya terkait dengan persoalan khas yang membutuhkan penanganan khusus.

d. UoS bisa membuat para wali bisa bersikap lebih fleksibel dalam menghadapi berbagai tipologi masyarakat. Terkait hal ini, ternyata kebijakan untuk mengawali dakwah dari wilayah pesisir adalah karena masyarakat pesisir relatif kooperatif.Mereka bisa menerima dakwah dengan cara konvensional. Sementara masyarakat pedalaman sangat terikat dengan unsur-unsur klasifikasi simbolik bernuansa Hindu/ Buddha sehingga para wali cenderung membiarkan local wisdom yang ada tetap berkembang. Adapun hal-hal yang dianggap bertentangan dengan Islam, secara pelan diluruskan sehingga bernuansa Islami. Itulah 
sebabnya cara ini disebut dengan pribumisasi Islam karena unsur pribumi lebih dominan.

\section{Kesimpulan dan Penutup}

Kesimpulan dari pembahasan ini adalah:

a. Penyebaran Islam pra walisongo adalah sebuah realitas yang dapat diterima secara logika berdasarkan bukti dari data-data yang ada.

b. Faktor yang menyebabkan kesenjangan antara data tentang penyebaran Islam pra walisongo dengan hasil perkembangan Islam setelah dilakukan penyebaran tersebut antara lain adalah:

- Kurangnya observasi dan follow up terhadap persoalan yang dihadapi oleh masyarakat;

- Prioritas kegiatan tidak fokus pada persoalan dakwah Islam melainkan pada urusan perdagangan;

- Intensitas pendampingan kurang karena mereka hanya datang ke Jawa untuk singgah dalam waktu yang sangat terbatas;

- Strategi dakwah tidak maksimal.

c. Implikasi etis yang bisa dipetik dari persoalan ini adalah:

- Observasi dakwah sangat penting supayafollow upyang akan dilakukan nanti lebih berdaya guna dan tepat sasaran;

- Para juru dakwah perlu memprioritaskan kegiatan dakwahnya di atas kegiatan yang lain ketika masyarakat yang mereka hadapi masih merasa asing dengan ajaran Islam;

- Pendampingan secara intensif itu penting supaya masyarakat tidak mudah lupa dengan apa yang telah diajarkan serta pemahaman mereka tentang Islam bisa lebih luas;

- Strategi dakwah merupakan upaya kreatif dari juru dakwah supaya hal-hal yang mereka sampaikan dapat diterima dengan baik dengan masyarakat. Dalam konteks ini terutama strategi berbasis kesatuan ilmu pengetahuan/ unity of sciences (UoS). Hal ini bisa membuat juru dakwah lebih kreatif dalam mengemas materi dakwahnya; lebih merakyat karena ada adaptasi dengan local wisdom; lebih efektif dan efisien dalam berdakwah karena dibantu berbagai teori pengetahuan; serta membuat mereka bisa bersikap fleksibel untuk berdakwah ke berbagai kalangan. 


\section{DAFTAR PUSTAKA}

Azra, Azyumardi, 2011, Jaringan Ulama Nusantara, Edisi Perrenial, Bandung: Pustaka Mizan

Esposito, John Louis, 2002, Ensiklopedia Oxford Dunia Islam Modern, Jilid 12, Bandung: Pustaka Mizan

Facione, Peter, 2011, Get the Fact p. 201, Reflective Reasoning for the Real World p. 128, on Think Critically (Paperback), London, Inggris: Pearson

Heidegger, Martin, 1962, Being and Time, a translation of Sein und Zeit by John Macquarrie and Edward Robinson, America: Harper and Row

Ibrahim, Salim, 2012 Kisah Walisongo Dilihat dari Beberapa Periode, http://salimibra.blogspot.co.id/2012/12/wali-songo-dari-beberapaperiode.html

Koentjaraningrat, 1984, Kebudayaan Jawa, Jakarta: Balai Pustaka

Nasution, Harun, 2008,Islam Ditinjau Dari BerbagaiAspeknya, UI, Jakarta Press, 2008: 50).

Samantho, Ahmad Yanuana, 2011, Peradaban Atlantis Nusantara, Jakarta: Ufuk Pers

Simon, Hasanu, 2007, Misteri Syekh Siti Jenar, Peran Walisongo dalam Mengislamkan tanah Jawa, Yogyakarta: Pustaka Pelajar

Sedyawati, 2001, Sejarah Kesusasteraan Jawa, Jakarta: Pustaka Media

Yamin, 1956, Atlas Dunia Islam, Jakarta: Djambatan 